\title{
Criminal Policy in Preventing Cyberharassment as a Negative Impact of Technology
}

\author{
W Frensh', M Mulyadi² \\ Law Program, Universitas Sumatera Utara, Medan, Indonesia \\ 11law weng@yahoo.com
}

\begin{abstract}
Information and communication technology develop fast nowadays. Advanced technology causes cybercrime. Cybercrime is criminal activity using computer and its network. One of the developing cybercrimes today is cyberharassment. New Jersey $2014 N J$ Rev Stat § 2C: 33-4.1describesthis crime while making a communication in an online capacity via any electronic device or through a social networking site and with the purpose to harras another. While the awareness of cyberharassment threat as a crime is still low in Indonesia, thereis no clear legal rule regarding this crime. This study used the theory of criminal policy and theory of criminal law reform. There are two impacts caused by the absence of the law. First, the difficulty of running a criminal policy. Second, cyberharassment has a psychological impactas a frustration, a depression, anda suicidal intention. The result of the researchshowedthat in terms of a penal policy, Indonesia applies the Electronic Information and Transactions LawNo.19 of 2016 in dealing with cyberharassment with article 27 paragraph 3 after comparing with New Jersey $2014 N J \operatorname{Rev}$ Stat $\S 2 C$ : 33-4.1 In terms of a nonpenal policy, ethics approach, technology approach, and journalistic approach.
\end{abstract}

Keywords: Technology, Cybercrime, Criminal

\section{INTRODUCTION}

Globalization creates relationships between countries around the world getting closer. The linkage of all countries in the world will lead to the development of information and communication technology [1]. The development of technology will create a bad impact with the emergence of cybercrime.Cybercrimeisperceived as a criminal use of a computer network or of othersystems on the internet, an attack or misuse of systems and networks to carry out criminal offenses [2]. The types of a cybercrimeincludephishing, sexting, password cracking, cyberterrorism, and hacking [3]. One of the developingcybercrimesis cyberharassment.

Cyberharassment as pertains to threatening or harassing email messages, instant messages, or to blog entries or websites dedicated solely to tormenting and individual [4]. The number of internet usersin 2017 has reached 143.26 million people, equivalent to 54.68 percent of the total population of Indonesia.It was announced by the Association of Internet Service Providers Indonesia (APJII) [5].

Based on the data obtained by UNICEF in2016, it is shown that 41 to 50 percent of teenagers in Indonesia, in the age range 13 to 15 years, have experienced cyberharassment measures.And, the most used social media sitesby cyberharassmentperpetratorswere Facebook, 
Instagram, Snapchat, and Twitter [6]. Cyberharassment has a harmfuleffect on itsvictimssuch as a psychological harm,a frustration, a depression and a suicidal intention [7] Teenagers have an important role to play in safeguarding the earth and the environment. If teenagers become victims of cyberharassment it will affect their real life. So that if teenagers do not become victims of cyberharassment, it will make teenagers can helpprotect the earth and the environment as sustainable development goal.

Therefore, a comparison is done with one of the countries that has complete rules and definition of cyberharassment action. New Jersey which is one of the states in America has a cyberharassment rule in New Jersey 2014NJ Rev Stat § 2C: 33-4.1. In addition, technological and communication developments exist in America, so of course, America has a policy and cyberharassment crime that uses technology as a means of crime.

In relation to legislation, Indonesiastill has nospecificrules on cyberharassment. The rulesonthismatter are stillgenerallyaccommodated in Law No. 19 of 2016 on Electronic Information and Transactions.

There is a need to compare how other countries applysuchlegislation to be a reference. Indonesianeeds to learn the best practice of other countries in copingwithcyberharassment and criminalpolicies to protect the children.

The problem of thisresearchwas: how shouldIndonesiaadoptCriminal policy in preventing cyberharassment as a negative impact of technology?

\section{METHOD}

This researchwas a normative legalresearch.Normative legal research is the study of positive legal norms, principles, principles and legal doctrines. In addition, italsoused a comparative juridicalstudy by conducting comparative studies of criminal law regulations in other countries in governing cyberharassment.The data werecollectedusingliteraturereviews and document analysisrelating to penal and non-penal policies. A criminal policy theory was applied in considering that the prevention of cyberharassment uses bothpenal and non-penal efforts.

\section{RESULT And DISCUSSION}

\subsection{Penal Policy on Cyberharassment}

John Barlow the person who first used the word cyberspace when we connect to the internet [8]. Harassment is repeatedly sending offensive, rude, and insulting messages often sent at all times of the day and nighty. Some may even post their messages to public forums, chat rooms or a bulletin board where others can view the threats [9]. The concept of harassment has evolved to now include four subcategories of harassment: physical, verbal, social orrelational, and cyberharassment [10] Williard (2007) describes cyberharassment: Repeatedly sending offensive, rude, and insulting messages [11].

\subsubsection{Law No. 19 of 2016 on Electronic Information and Transaction (EIT)}

Based on the provisions of the articles of Chapter XI concerning the criminal provisions of the EIT Law, someprohibitedacts (elements of criminal offense) that are closelyrelated to cyberharassment in each article canbeidentified as follows: 
Article 27 Paragraph 3 stipulates the prohibition to distribute, transmit and make accessible anyform of Electronic Information or Electronic Document which has contents of an insult or defamation. The wordinsultcategorized in cyberspace comesunderthe type of cyberharassment.

The elements of crime contained in the Laware as follows:

- Deliberately.Deliberatelymeans carefully think or talk something through by knowing the consequences of the actions. In harassing, and act is done by sending rude messages to insult somebody. The act explains that the perpetrator makes a very conscious, well-thought choice because the actor knows the consequences of his action. In this matter, the element of deliberately is filled.

- Withoutrightsis an actagainst the lawthatviolates the provisions of the legislation.In cyberharassment, withoutrightsmeansthat the offender has no legal permission to do so.

- Distribute and/or transmit and/or make accessible anyform of Electronic Information and/or Electronic Documents.Distributingmeans sharing or submittingsomething. Distributingheremeans to send an electronic information or electronic document, either to someone or some parties by utilizing the information and communication technology. The otherelement, transmitting, includesending or forwarding an electronic information or electronic document to somebody.Distributingsharessomething to many people, whiletransmitting to one persononly.

- Havingharassing content in the EIT Lawrefers to the provisions of a fulmination or set forth inCriminal Code (Penal Code). The essence of an insultin the EIT and the Penal Code is an act of attacking the honor or reputation of others in order to beknown by the public.

\subsubsection{New Jersey 2014NJ Rev Stat § 2C: 33-4.1.}

The comparative law has an intrinsic purpose emphasises its role in legal research and education. Knowledge of foreign laws is valuable where these laws are relevant for the domestic legal system [12]. Cyberharassmentlegislationisregulated in one of the American States calledNew Jersey.The definition of cyberharassment and what kind of actions categorized into cyberharassment can be found in New Jersey 2014NJ Rev Stat § 2C: 334.1.So, itisnecessary to know the rules of cyberharassment in New Jersey as part of a comparative lawstudy, giventhat the information and knowledge have connected people around the world.

New Jersey 2014NJ Rev Stat § 2C: 33-4.1describes cyberharassment while making a communication in an online capacity via any electronic device or through a social networking site and with the purpose to harras another.

Via any electronic device or through a social networking sitemeans it refers to textual, visual, written or oral communication using online computer service, internet, telephone or other communication means such as chat rooms, electronic mails, social networking sites and online messaging service.

To harass other means to insult or use rude words to attack somebody's honor. It has been regulated in each criminal provision of the EIT Law. If the act is to harass purposedly then the act will be regulated in Article 27 Paragraph 3 oninsult. 


\subsection{Non-Penal Policy on Cyberharassment}

\subsubsection{Ethics Approach}

Parent, teacher and environment are very important in tackling cyberharassment [13]. Parent must educate their children on appropriate behavior and also teach their children what to do if they become involved in a cyberharassment incident. Teacher must be aware of the problem and be able to take actions that will both teach their student how to protect themselves and how to avoid being a victim or perpetrator of cyberharassment.

\subsubsection{TechnologyApproach}

Parental control applications and filters are used to protect children's security on the internet [14]. Technology has helped us to connect and learn from each other in ways that most of us never imagined. It helps us to explore all benefits to our lives. As with many things, it is not the technology, but the misuse of it, that creates problems. As responsible parents and educators have an obligation to understand the potential uses of new technologies and guide young people in their responsible implementation of them.

\subsubsection{Journalistic Approach}

The role of the journalism plays an important role to keep the child from becoming a victim of cyberharassment action. When child is dealing with legal cases, journalists and reporters should keep their identity secret and do not take pictures of children if they see the potential of the childs news publication will have an impact on the child psychologically.

\section{CONCLUSIONS}

The findingsshow that the existingcriminalpolicies in Indonesia on cyberharassment, both in terms of penal and non-penalpolicies,canbeused in overcoming cyberharassmentproblems. In terms of a penalpolicy,Indonesiaapplies the EIT Law No. 19 of 2016 in dealing with cyberharassment with article 27 paragraph 3 after comparing with New Jersey 2014NJ Rev Stat $\S 2$ C: 33-4.1. In terms of a non-penalpolicy, ethics approach, technologicalapproach, and journal

\section{REFERENCES}

[1] S. D. Spiegeleire, Artificial Integlligence and the Future of Defense: Strategic Implications for Small and Medium Sized Force Providers. Hoboken: Wiley-ISTE, 2014.

[2] I. Bernik, Cyber Crime and Cyber Warfare. Hoboken: Wiley-ISTE, 2014.

[3] J. B. Hill and N. E. Marison, Introduction to Cybercrime: Computer Crimes, Law, and Policing in the 21st Century. Florida: Praeger, 2016.

[4] N. E. Williard, Cyber Savvy: Embracing Digital Safety and Civility. London: Corwin Press, 2007.

[5] A. Fadli and A. B. Putra, "Internet Users in Indonesia Reach 143 Million People in 2017," Industry. [Online]. Available: http://en.industry.co.id/read/3943/internet-usersin-indonesia-reach-143-million-people-in-2017.

[6] R. Holmes, Eradicating Cyber Bullying: Through Online Training, Reporting \& Tracking System. Bloomington: Author House, 2017. 
[7] C. Markum, Cyber Crime. New York: Wolters Kluwer Law\& Business, 2014.

[8] S. Thomas, Technobiophilia: Nature and Cyberspace. London: Bloomsbury Publishing, 2013.

[9] S. Chadwick, "Cyberbullying," in SpringerBriefs in Education, Springer International Publishing, 2014, pp. 11-29.

[10] S. Anderson, No More Bystanders = No More Bullies: Activating Action in Educational Professionals. Thousand Oaks: Corwin Press, 2011.

[11] N. E. Williard, Cyber Safe Kids, Cyber Savvy Teens: Helping Young People Learn to Use the Internet Safely and Responsibly, Trans.N. Yusron. Jakarta: Nusa Media, 2007.

[12] M. Siems, Comparative Law. New York: Cambridge University Press, 2014.

[13] C. Cunha and M. Manuela, Handbook of Research on Digital Crime, Cyberspace Security, and Information Assurance. United States of America: IGI Global, 2014.

[14] F. Schargel, Dropout Prevention Fieldbook: Best Practices from the Field. New York: Routledge, 2011. 